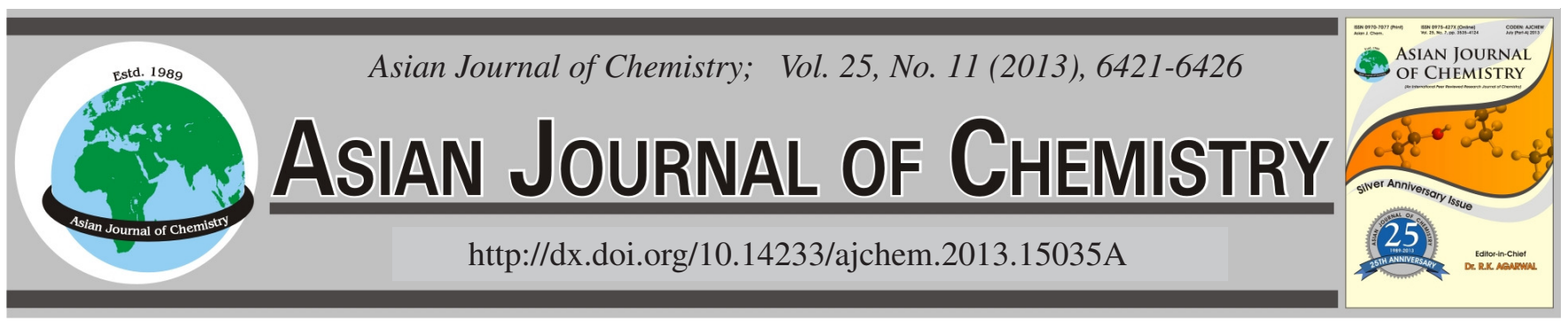

\title{
Electrochemical Determination of $\beta$-Blocker Alprenolol Hydrochloride in Its Pharmaceutical Formulations
}

\author{
Nawal A. Alarfaj* and Maha F. El-Tohamy
}

Department of Chemistry, College of Science, King Saud University, P.O. Box 22452, Riyadh 11495, Saudi Arabia

*Corresponding author: Tel/Fax: +966 1 4772245; E-mail: nalarfaj@ hotmail.com

\section{INTRODUCTION}

Alprenolol hydrochloride, 1-[(1-methyl ethyl) amino]3-[2-(prop-2-enyl) phenoxy] propan-2-ol hydrochloride is one of the adrenergic $\beta$-antagonists used as anti-hypertensive, antianginal and anti-arrhythmic agent ${ }^{1}$ (Fig. 1).<smiles>C=CCc1ccccc1OCC(O)CNC(C)C</smiles>

Fig. 1. Chemical structure of alprenolol hydrochloride

Several methods have been reported for the determination of alprenolol hydrochloride, including high performance liquid chromatography ${ }^{2-4}$, gas chromatography coupled with mass spectrometry ${ }^{5-7}$ and capillary electrophoresis ${ }^{8,9}$. Although potentiometric methods of analysis using ion-selective electrodes are simple, low cost and applicable to samples, no selective electrode is so far available for the determination of alprenolol hydrochloride. This work describes new selective membrane electrodes of two types i.e., plastic membrane (I) and coated wire electrode (II) for the determination of alprenolol hydrochloride in pure form and in its pharmaceutical formulations.

\section{EXPERIMENTAL}

Standard drug solution: Stock alprenolol hydrochloride solution $\left(1.0 \times 10^{-1} \mathrm{~mol} / \mathrm{L}\right)$ was prepared daily by dissolving an appropriate amount of the drug in distilled water. More dilute solutions were prepared by appropriate dilution using double distilled water.

Preparation of alprenolol-phosphomolybdate ion-pair: The ion-pair was prepared by mixing stoichiometric amounts of $1.0 \times 10^{-2} \mathrm{~mol} / \mathrm{L}$ phosphomolybdic acid with an equimolar solution of alprenolol hydrochloride, stirred for $10 \mathrm{~min}$. The resulting yellowish precipitate was filtered through G4 sintered glass crucible and washed thoroughly with deionized water then dried at room temperature for $24 \mathrm{~h}$. The ion-pair should be stored in a desiccator.

Membrane composition: The membrane composition was studied by varying the percentages $(w / w)$ of the ion pair, poly (vinyl chloride) PVC and plasticizer $o$-nitrophenyl octyl ether (o-NPOE), until the optimum composition that exhibits the best performance characteristics was obtained. The membranes were prepared by dissolving the required amount of the ion-pair i.e., PVC and $o$-NPOE, in $5 \mathrm{~mL}$ tetrahydrofuran. The solution mixture was poured into a petri dish $(3 \mathrm{~cm}$ in diameter), covered with a filter paper and the solvent was allowed to evaporate slowly at room temperature. To obtain 
TABLE- 1

OPTIMIZATION OF MEMBRANE COMPOSITION (w/w \%) OF ALPRENOLOL SENSORS

\begin{tabular}{lcccccccc}
\hline Types of sensors & $\mathrm{m}$ & $\mathrm{PVC}(\mathrm{w} \%)$ & $o$-NPOE $(\mathrm{w} \%)$ & Ion-pair $(\mathrm{w} \%)$ & Slope & RSD $(\%)$ & $\mathrm{r}$ & Linear conc. range \\
\hline Plastic membrane & (a) & 45.0 & 45.0 & 10.0 & 58.54 & 0.2 & 0.9999 \\
electrode & (b) & 46.0 & 46.0 & 8.0 & 55.48 & 0.4 & 0.9993 \\
& (c) & 48.0 & 48.0 & 4.0 & 52.69 & 1.2 & 0.9996 & $1.0 \times 10^{-6}-1.0 \times 10^{-2}$ \\
& (a) & 45.0 & 45.0 & 10.0 & 57.83 & 0.4 & 0.9999 & $5.0 \times 10^{-5}-1.0 \times 10^{-6}-1.0 \times 10^{-2}$ \\
\hline Coated wire & (b) & 46.0 & 46.0 & 8.0 & 54.83 & 0.9 & 0.9995 \\
electrode & (c) & 48.0 & 48.0 & 4.0 & 50.97 & 0.6 & 0.9993 & $5.0 \times 10^{-5}-1.0 \times 10^{-2}$ \\
\hline
\end{tabular}

the uniform membrane thickness, the amount of tetrahydrofuran was kept constant and its evaporation was fixed for $24 \mathrm{~h}$.

\section{Electrode construction}

Plastic membrane electrode: A punched circular membrane was attached to a poly-ethylene tube $(8 \mathrm{~mm}$ in diameter) in an electrode configuration by means of PVCTHF solution. A mixture containing equal volumes of $1 \times 10^{-3}$ $\mathrm{mol} / \mathrm{L}$ alprenolol hydrochloride and potassium chloride was used as internal reference solution in which the $\mathrm{Ag} / \mathrm{AgCl}$ reference electrode was dipped. The constructed electrode was pre-conditioned after preparation by soaking for $6 \mathrm{~h}$ in $1 \times 10^{-3}$ $\mathrm{mol} / \mathrm{L}$ alprenolol hydrochloride and stored in the same solution. All potentiometric measurements were performed using the following cell assembly: $\mathrm{Ag} / \mathrm{AgCl} /$ internal solution/membrane/ test solution//KCl salt bridge//SCE.

Coated wire electrode: Pure aluminum wire of $4 \mathrm{~cm}$ length was tightly insulated by polyethylene tube leaving 1 $\mathrm{cm}$ at one end for the coating and $0.5 \mathrm{~cm}$ at the other end for connection. The coating solution was described previously under membrane composition. Prior to coating, the polished aluminum surface was washed with a detergent, thoroughly rinsed with distilled water and dried with acetone. Then the wire was rinsed with chloroform and allowed to dry. Afterwards, the aluminum wire was coated by quickly dipping it into the coating solution several times and allowing the film left on the wire to dry for about $3 \mathrm{~min}$. The process was repeated several times until a plastic membrane of approximately $1 \mathrm{~mm}$ thickness was formed. The prepared electrode was conditioned by soaking for $4 \mathrm{~h}$ in $1 \times 10^{-3} \mathrm{~mol} / \mathrm{L}$ alprenolol hydrochloride solution. All potentiometric measurements were performed using the following cell assembly: Al/membrane/test solution/ $/ \mathrm{KCl}$ salt bridge//SCE.

\section{Determination of alprenolol hydrochloride in dosage forms}

Aptine $^{\circledR}$ tablets: Ten aptine tablets $(200 \mathrm{mg} /$ tablet $)$ were finely powdered and accurate weight equivalent to prepare $1 \times 10^{-2} \mathrm{~mol} / \mathrm{L}$ was prepared using distilled water. Serial dilutions were made to obtain different concentrations in the range of $1 \times 10^{-5}-1 \times 10^{-2} \mathrm{~mol} / \mathrm{L}$, of alprenolol hydrochloride for both electrodes (I) and (II). The prepared solutions were adjusted to $\mathrm{pH} 4$ using $0.1 \mathrm{~mol} / \mathrm{L}$ hydrochloric acid. The alprenolol-electrode(s) was immersed in the solution. The electrode(s) system was allowed to equilibrate with stirring and the e.m.f. recorded and compared with the calibration graph.

Content uniformity assay of aptine ${ }^{\circledR}$ tablets: Ten individual tablets of aptine ${ }^{\circledR}(200 \mathrm{mg} /$ tablet $)$ were placed separately in $100 \mathrm{~mL}$ volumetric flask and dissolved in $25 \mathrm{~mL}$ distilled water, then completed to volume with distilled water. The electrode(s) was directly immersed into $10 \mathrm{~mL}$ of each sample solution for five times and should be washed with deionized water to reach steady potential between the individual measurements. The mean potential was used to evaluate the content uniformity from the calibration graph.

\section{RESULTS AND DISCUSSION}

Optimization of membrane composition: In this study three membrane compositions were investigated, the results were summarized in Table-1. The results showed that the electrode(s) made by membrane of type (a) with $10 \mathrm{w} \%$ alprenolol-phosphomolybdate ion pair, $45 \mathrm{w} \% \mathrm{PVC}$ and 45 w \% plasticizer $o$-nitrophenyl octyl ether exhibited the best performance characteristics $(58.54 \pm 0.2$ and $57.83 \pm 0.4 \mathrm{mV} /$ decade at $25^{\circ} \mathrm{C}$ ) for electrodes (I) and (II) respectively, over alprenolol hydrochloride concentration ranges from $3 \times 10^{-6}$ $1 \times 10^{-2}$ and $5 \times 10^{-6}-1 \times 10^{-2} \mathrm{~mol} / \mathrm{L}$ for the previously mentioned electrodes respectively.

Nature and response characteristics of the electrodes: Alprenolol reacts with phosphomolybdic acid to form a stable alprenolol-phosphomolybdate ion-pair complex which is water insoluble but readily soluble in an organic solvent such as tetrahydrofuran. The complex was prepared and tested as active material with $o$-nitrophenyl octyl ether as a solvent mediator in a poly (vinyl chloride) membrane response for alprenolol. The critical response characteristics of plastic membrane and coated wire electrodes were determined and results are summarized in Table-2. The electrode(s) exhibited a Nernstain response over the concentration ranges from $3 \times 10^{-6}-1 \times 10^{-2}$ and $5 \times$ $10^{-6}-1 \times 10^{-2} \mathrm{~mol} / \mathrm{L}$ alprenolol hydrochloride with slopes of $58.54 \pm 0.2$ and $57.83 \pm 0.4 \mathrm{mV} /$ decade at $25^{\circ} \mathrm{C}$ for electrodes (I) and (II), respectively as shown in Fig. 2. The choice of THF as a membrane solvent to achieve the required selectivity is based on its electric permitivity and its immiscibility with aqueous phase, high viscosity, low solubility of the matrix in the membrane and ability to dissolve ion-pair complex.

Life time: The response time of the electrode(s) was tested for $3 \times 10^{-6}-1 \times 10^{-2} \mathrm{~mol} / \mathrm{L}$ alprenolol hydrochloride solutions. The sequence of measurements was from low to high concentrations. The electrode(s) exhibited a fast and dynamic response of 35 and $\leq 25 \mathrm{~s}$ for a period of 30 and 35 days for electrodes (I) and (II) respectively, without significant change in the electrode(s) parameters.

Effect of plasticizer: In this study, three plasticizers, di-butylphthalate (DBP), di-octylphthalate (DOP) and $o$ nitrophenyl octyl ether (o-NPOE) were used to examine the optimization of the membrane with plasticizer entailed the use of plasticizer content ratio, 45, 46 and $48 \mathrm{w} \%$ and the use of PVC contents of 45,46 and $48 \mathrm{w} \%$. The electroactive compound (alprenolol-phosphomolybdate) contents were 10, 8 and 
TABLE- 2

CRITICAL RESPONSE CHARACTERISTICS OF ALPRENOLOL-PHOSPHOMOLYBDATE SENSORS

\begin{tabular}{|c|c|c|}
\hline Parameter $^{a}$ & $\begin{array}{c}\text { Alprenolol-phosphomolybdate plastic membrane } \\
\text { electrode }\end{array}$ & $\begin{array}{l}\text { Alprenolol-phosphomolybdate coated wire } \\
\text { electrode }\end{array}$ \\
\hline Slope (mV/decade) & $58.54 \pm 0.2$ & $57.83 \pm 0.4$ \\
\hline Intercept & 329.39 & 396.24 \\
\hline Correlation coefficient (r) & 0.9999 & 0.9999 \\
\hline Linear range $(\mathrm{mol} / \mathrm{L})$ & $3.0 \times 10^{-6}-1.0 \times 10^{-2}$ & $5.0 \times 10^{-6}-1.0 \times 10^{-2}$ \\
\hline Detection limit $(\mathrm{mol} / \mathrm{L})$ & $1.6 \times 10^{-6}$ & $2.5 \times 10^{-6}$ \\
\hline Response time for $10^{-3} \mathrm{~mol} / \mathrm{L}(\mathrm{s})$ & 35 & $\leq 25$ \\
\hline Working $\mathrm{pH}$ range & $3-8$ & $3-8$ \\
\hline Lifetime/day & 30 & 35 \\
\hline Accuracy (\%) & 99.89 & 99.32 \\
\hline Standard deviation & \pm 0.5 & \pm 0.4 \\
\hline Repeatability (\% RSD) & 0.8 & 0.6 \\
\hline Between day variability (\% RSD) & 0.9 & 0.7 \\
\hline Robustness $^{b^{b}}$ & $99.75 \pm 0.445$ & $99.56 \pm 0.610$ \\
\hline Ruggedness $^{\mathrm{c}}$ & $99.82 \pm 0.576$ & $99.24 \pm 0.356$ \\
\hline
\end{tabular}

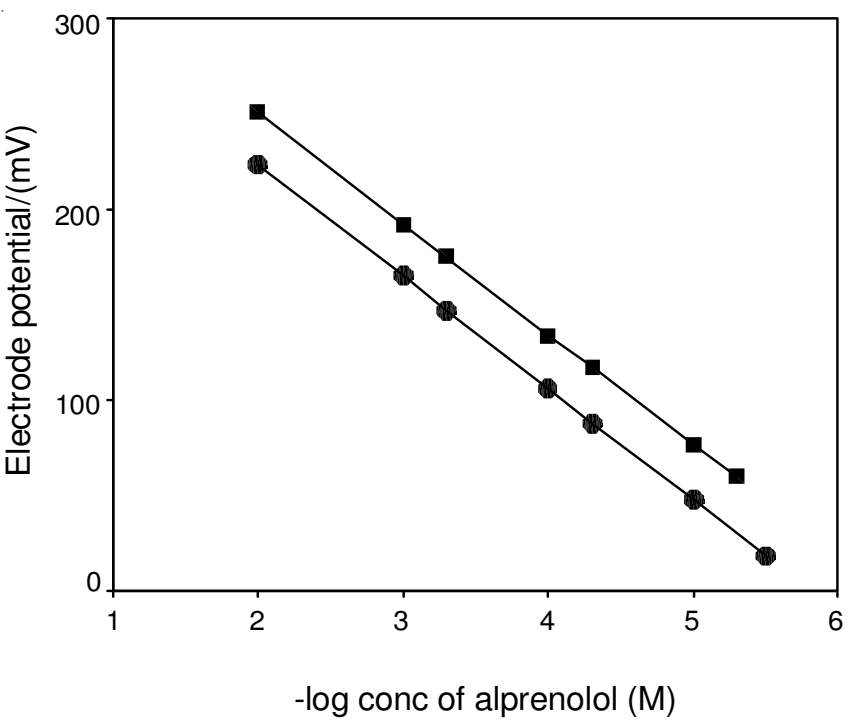

Fig. 2. Typical calibration graph of alprenolol-phosphomolybdate sensors: (O) plastic membrane electrode, $(\square)$ coated wire- electrode

$4 \mathrm{w} \%$. The results obtained showed that the response performances of the prepared membranes were rather different depending on the use of plasticizer, the proportion of the plasticizer towards PVC and of the electroactive compound. The typical potential responses of the electrodes constructed with three plasticizers were given in Fig. 3. As shown in Fig. 3 , the $o$-NPOE-PVC electrodes were superior to DBP- and DOP-PVC electrodes in both the response slope and linear concentration range. So $o$-NPOE was selected as the plasticizer of the membranes. The best membrane composition of the $o$-NPOE-PVC electrode(s) was $45 \mathrm{w} \% \mathrm{PVC}, 45 \mathrm{w} \% o$-NPOE and $10 \mathrm{w} \%$ ion-pair.

Effect of soaking: The performance characteristics of the alprenolol-phosphomolybdate electrode(s) was studied as a function of soaking time. For this purpose the electrode(s) was soaked in $1 \times 10^{-3} \mathrm{~mol} / \mathrm{L}$ solution of alprenolol, the calibration graphs were plotted and the optimum soaking time was found to be $6 \mathrm{~h}$ and $4 \mathrm{~h}$ at which the slope of the calibration curve was $58.54 \pm 0.2$ and $57.83 \pm 0.4 \mathrm{mV} /$ decade, at $25^{\circ} \mathrm{C}$ for electrodes (I) and (II) respectively. The influence of prolonged

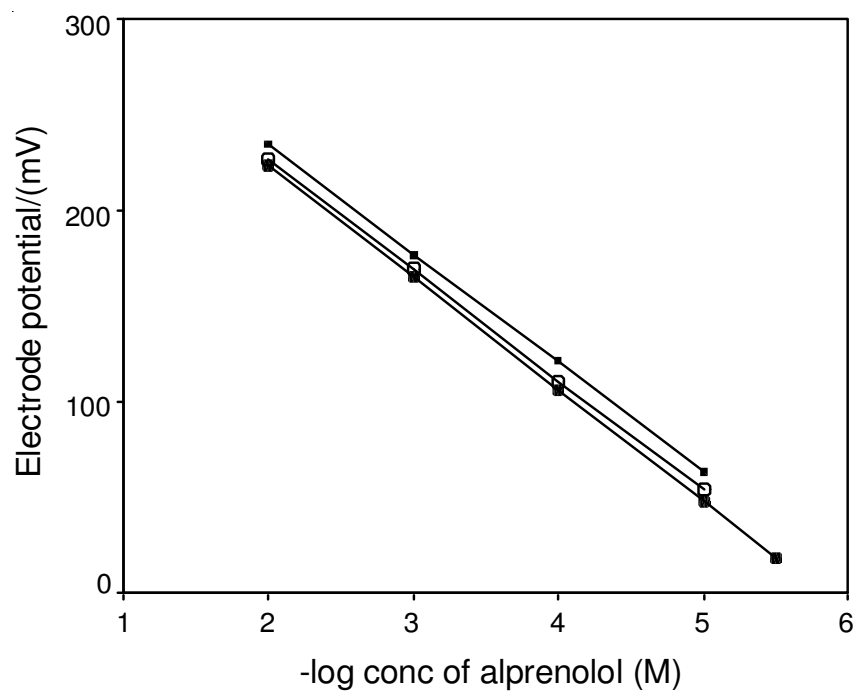

Fig. 3. Optimization of plasticizers. $o$-NPOE (O) (PVC membrane composition: $o$-NPOE $45 \mathrm{w} \%$, PVC $45 \mathrm{w} \%$, ion-pair, $10 \mathrm{w} \%$ ), DOP $(\square)$ (PVC membrane composition: DOP $46 \mathrm{w} \%$, PVC $46 \mathrm{w}$ $\%$, ion pair, $8 \mathrm{w} \%$ ), DBP ( $\mathrm{\square}$ PC membrane composition: DBP $48 \mathrm{w} \%$, PVC $48 \mathrm{w} \%$, ion-pair, $4 \mathrm{w} \%$ )

soaking on the lifetime of alprenolol-phosphomolybdate electrode(s) was followed by constructing calibration plots. The electrode(s) was soaked continuously on $1 \times 10^{-3} \mathrm{~mol} / \mathrm{L}$ solution of alprenolol hydrochloride for $24 \mathrm{~h}, 7,15,20,28$ and 30 days. The calibration plot slopes decreased slightly to $55.65,53.87 \mathrm{mV} /$ decade after 28 and 30 days for electrodes (I) and (II), respectively. Figs. 4 and 5 show the effect of prolonged soaking time and the lifespan of the alprenololphosphomolybdate electrodes.

Regeneration of the electrode: The above discussion revealed that soaking of the electrode(s) in the drug solution for a long time has a negative effect on the response of the membrane towards alprenolol. The same effect appears after working with the electrode(s) for a long time. The regeneration of the electrode(s) was tried simply by reformation of the ion-exchange on the external gel layer of membrane ${ }^{10}$. The regeneration of alprenolol-phosphomolybdate membrane was successfully achieved by soaking the exhausted electrode(s) 


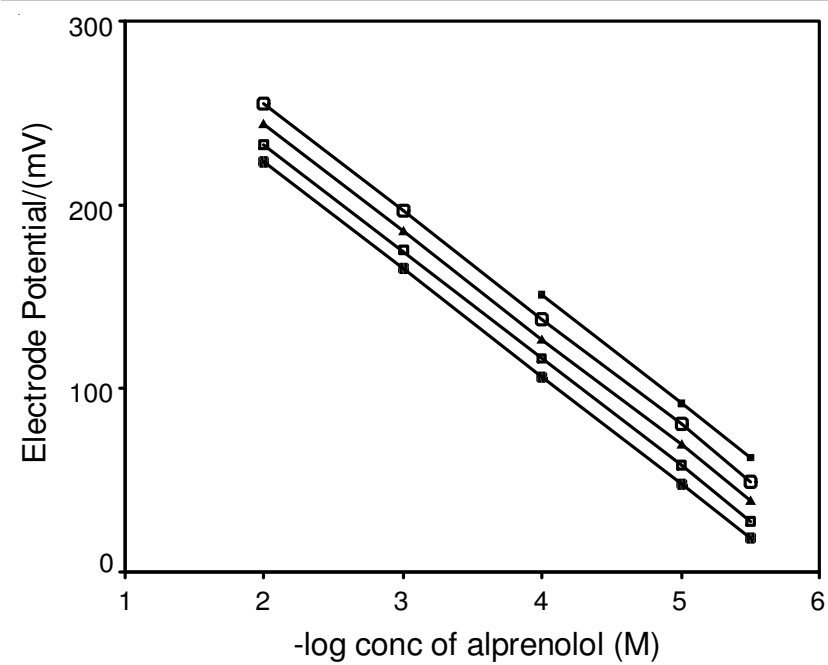

Fig. 4. Calibration graphs obtained at $25 \pm 1{ }^{\circ} \mathrm{C}$ after soaking the alprenololphosphomolybdate plastic membrane electrode for $(2) 24 \mathrm{~h}, \square$ 7 days, ( $(\mathbf{\Delta}) 15$ days, (O) 20 days and $\square 30$ days

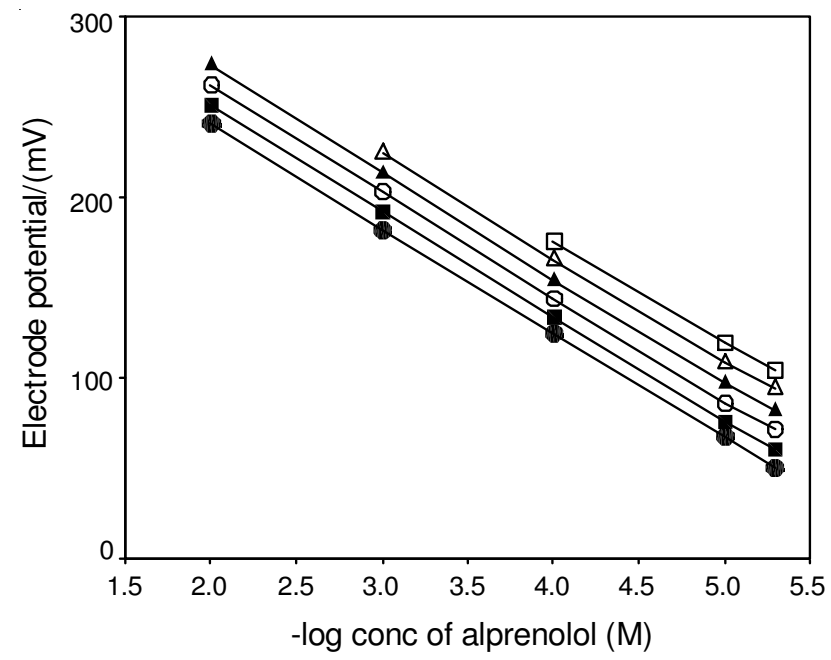

Fig. 5. Calibration graphs obtained at $25 \pm 1{ }^{\circ} \mathrm{C}$ after soaking the alprenololphosphomolybdate coated wire electrode for $(24 \mathrm{~h},(\square) 7$ days, (○) 15 days, $(\mathbf{\triangle}) 20$ days and $(\triangle) 30$ days and $(\square) 35$ days

for $24 \mathrm{~h}$ in a solution that was $1 \times 10^{-2} \mathrm{~mol} / \mathrm{L}$ phosphomolybdic acid, followed by soaking for $3 \mathrm{~h}$ in $1 \times 10^{-2} \mathrm{~mol} / \mathrm{L}$ alprenolol solution. Figs. 6 and 7, show the calibration graphs for an exhausted electrode(s) (slopes 55.65, $53.87 \mathrm{mV} /$ decade) for electrodes (I) and (II) respectively and for the same electrode(s) after regeneration (slopes 56.59, $55.18 \mathrm{mV} /$ decade) for electrodes (I) and (II), respectively. It was found that the lifespan of the regenerated electrode(s) is limited to $3 \mathrm{~h}$ due to the ease of leaching of the lipophilic salts from the gel layer at the electrode(s) surface compared with those that are attached homogeneously to the PVC network through the solvent mediator.

Effect of pH: The effect of $\mathrm{pH}$ of the alprenolol solution using $1 \times 10^{-3} \mathrm{~mol} / \mathrm{L}$ alprenolol hydrochloride on the electrode(s) potential was investigated. The solution was acidified by the addition of very small volumes of $0.1 \mathrm{~mol} / \mathrm{L}$ hydrochloric acid then the $\mathrm{pH}$ value was increased gradually using $0.1 \mathrm{~mol} / \mathrm{L}$ sodium hydroxide for each $\mathrm{pH}$ value, the potential was recorded and thus the potential-pH curves for alprenolol concentration were constructed (Fig. 8). The $\mathrm{pH}$ range was 3-8 for both electrodes. The electrode(s) potential is practically independent of $\mathrm{pH}$ and in this range the electrode(s) can be safely used for alprenolol hydrochloride determination.

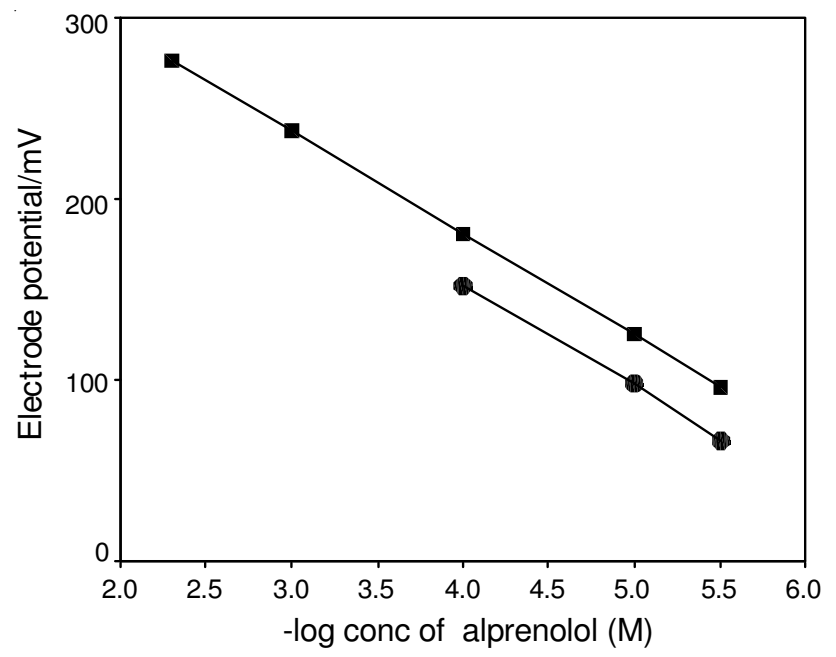

Fig. 6. Regeneration of alprenolol-phosphomolybdate plastic membrane sensor $(\bigcirc)$ exhausted electrode $(\square)$ regenerated electrode

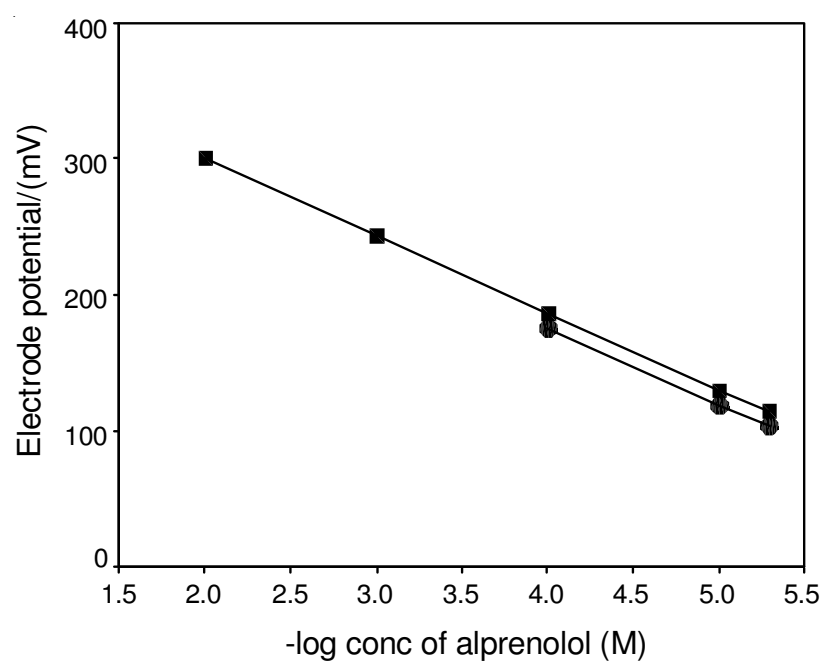

Fig. 7. Regeneration of alprenolol-phosphomolybdate coated wire sensor $(\bigcirc)$ exhausted electrode $(\square)$ regenerated electrode

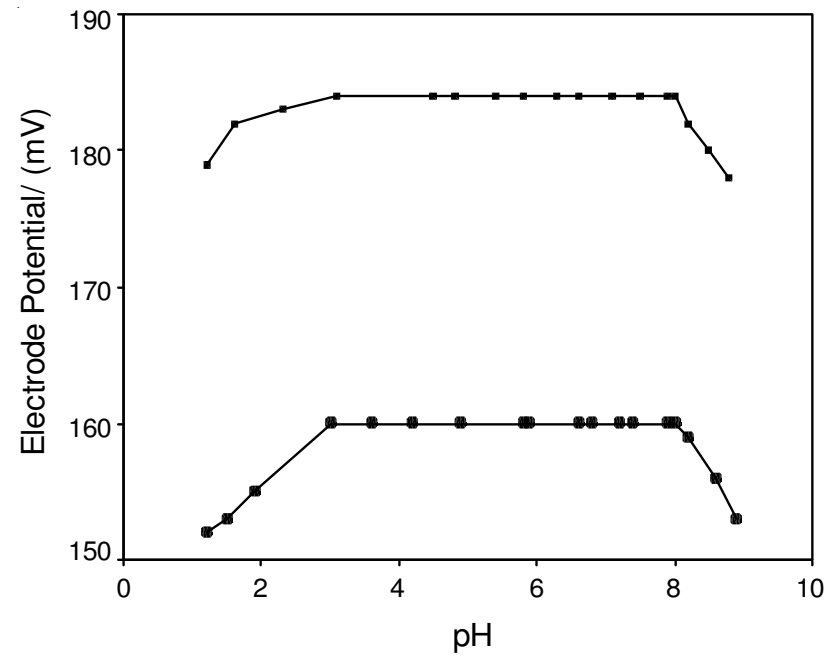

Fig. 8. Effect of $\mathrm{pH}$ on potential $/ \mathrm{mV}$ of alprenolol sensors using $1 \times 10^{-3}$ (O) Electrode potential $/ \mathrm{mV}$ for plastic membrane electrode, Electrode potential $/ \mathrm{mV}$ for coated wire electrode 
Selectivity of the electrode: The influence of various basic substances on the response of alprenolol hydrochloride sensors was investigated by measuring the potentiometric interference from different kinds of sugars, inorganic cations, certain alkaloids and amino acids. The selectivity coefficients were evaluated by the separate solution method. Table-3 showed that the proposed alprenolol-phosphomolybdate membrane electrode(s) is highly selective towards alprenolol hydrochloride. The electrode(s) showed no response to a number of potentially interfering ionic excipients usually used in the manufacturing of the pharmaceutical preparations, such as starch and lactose. The inorganic cations did not interfere due to the differences in their mobilities and permiabilities as compared with alprenolol cation. In the case of amino acids, the high selectivity is mainly attributed to the difference in polarity and lipophilic character of their molecules relative to alprenolol.

TABLE- 3

SELECTIVITY COEFFICIENTS OF THE ALPRENOLOLPHOSPHOMOLYBDATE SENSORS CALCULATED BY SEPARATE SOLUTION METHOD $\left(1 \times 10^{-3} \mathrm{~mol} / \mathrm{L}\right.$ OF BOTH ALPRENOLOL AND INTERFERENT AT $25^{\circ} \mathrm{C}$ )

\begin{tabular}{lcc}
\hline & \multicolumn{2}{c}{$\mathrm{K}^{\text {pot }}$ tetr. } \\
\cline { 2 - 3 } Interferent & $\begin{array}{c}\text { Alprenolol- } \\
\text { phosphomolybdate } \\
\text { plastic membrane }\end{array}$ & $\begin{array}{c}\text { Alprenolol- } \\
\text { phosphomolybdate } \\
\text { coated wire }\end{array}$ \\
\hline Sodium chloride & $3.7 \times 10^{-3}$ & $5.6 \times 10^{-3}$ \\
Potassium chloride & $4.8 \times 10^{-3}$ & $2.3 \times 10^{-3}$ \\
Ammonium chloride & $4.0 \times 10^{-3}$ & $5.6 \times 10^{-3}$ \\
Calcium chloride & $1.2 \times 10^{-3}$ & $1.1 \times 10^{-3}$ \\
Magnesium chloride & $4.5 \times 10^{-3}$ & $2.9 \times 10^{-3}$ \\
Urea & $2.7 \times 10^{-3}$ & $5.8 \times 10^{-3}$ \\
Quinidine & $8.5 \times 10^{-3}$ & $2.8 \times 10^{-3}$ \\
Atropine sulphate & $4.1 \times 10^{-4}$ & $1.7 \times 10^{-4}$ \\
Lactose & $5.6 \times 10^{-4}$ & $9.2 \times 10^{-4}$ \\
Maltose & $1.9 \times 10^{-3}$ & $7.4 \times 10^{-4}$ \\
Glucose & $3.5 \times 10^{-3}$ & $7.7 \times 10^{-4}$ \\
L-leucine & $4.6 \times 10^{-3}$ & $2.3 \times 10^{-3}$ \\
L-Valine & $7.7 \times 10^{-4}$ & $4.4 \times 10^{-3}$ \\
L-Cystine & $2.9 \times 10^{-4}$ & $6.7 \times 10^{-3}$ \\
Starch & $3.0 \times 10^{-4}$ & $9.8 \times 10^{-4}$ \\
Propranolol hydrochloride & $2.4 \times 10^{-3}$ & $6.3 \times 10^{-3}$ \\
Atenolol & $5.6 \times 10^{-3}$ & $3.3 \times 10^{-3}$ \\
\hline
\end{tabular}

Quantification of alprenolol: Direct potentiometric determination of alprenolol hydrochloride using alprenololphosphomolybdate electrode(s) type (I) and (II) was performed and calculated from the calibration curve. The direct potentiometric determination of alprenolol in pure form using the proposed electrodes gave average \% recovery of $99.89 \pm 0.494$ and $99.32 \pm 0.391$ for electrodes (I) and (II) respectively. Furthermore, the results obtained were compared with those of the official method ${ }^{11}$, which involved a potentiometric titration using $0.1 \mathrm{~mol} / \mathrm{L}$ sodium hydroxide, for determination of alprenolol hydrochloride and the results are listed in Table-4.

\section{Validation of the proposed method}

Linearity: Under the optimal experimental ion selective electrode conditions, a linear relationship exists between the electrode potential $/ \mathrm{mV}$ and the logarithm of corresponding concentration of the investigated drug. The regression data, correlation coefficient ( $r$ ) and other statistical parameters were previously listed in Table-2.
TABLE- 4

DETERMINATION OF ALPRENOLOL IN PURE FORM USING ALPRENOLOL-PHOSPHOMOLYBDATE SENSORS IN COMPARISON WITH OFFICIAL METHOD

\begin{tabular}{ccc|cc}
\hline \multirow{2}{*}{$\begin{array}{c}\text { Statistical } \\
\text { parameter }\end{array}$} & \multicolumn{2}{c|}{ Plastic membrane electrode } & \multicolumn{2}{c}{ Coated wire electrode } \\
\cline { 2 - 5 } & $\begin{array}{c}\text { Official } \\
\text { method }^{11}\end{array}$ & $\begin{array}{l}\text { Calibration } \\
\text { method }\end{array}$ & $\begin{array}{l}\text { Official } \\
\text { method }^{11}\end{array}$ & $\begin{array}{c}\text { Calibration } \\
\text { method }\end{array}$ \\
\hline Mean \% & 99.73 & 99.89 & 99.10 & 99.32 \\
n & 6.00 & 6.00 & 6.00 & 6.00 \\
Variance & 0.244 & 0.282 & 0.445 & 0.153 \\
\pm SD & 0.494 & 0.531 & 0.198 & 0.391 \\
SE & 0.221 & 0.217 & 0.182 & 0.160 \\
RSD & 0.496 & 0.532 & 0.451 & 0.394 \\
$t$-test & \multicolumn{5}{c}{$0.907(2.228)^{*}$} \\
$F$-test & $1.16(5.05)^{*}$ & & $2.91(5.05)^{*}$ \\
\hline Theoretical values of $t$ and $F$ at $\mathrm{P}=0.05$
\end{tabular}

Detection limit: The detection limit of the investigated drug was calculated according to IUPAC ${ }^{12}$ recommendation which stated that the detection limit is the concentration at which the measured potential differs from that predicted by the linear regression by more than $18 \mathrm{mV}$. The values were previously reported in Table-2; indicate that the proposed method is sensitive for detection of very small concentrations of alprenolol hydrochloride.

Robustness and ruggedness: The robustness of the proposed ion selective electrode method was tested by investigating the capacity of the method to remain unaffected by a small but a deliberate variation in method parameters and provide an indication of its reliability during normal usage ${ }^{13}$. The robustness of the proposed method was carried out by using phosphate buffer $\mathrm{pH} 6 \pm 1$ and the percentage recoveries were $99.75 \pm 0.445$ and $99.56 \pm 0.610$ for the two prepared electrodes, these results were closely in agreement with those obtained from standard drug solutions, (Table-2). While the ruggedness of the proposed method was investigated by measuring the degree of reproducibility at test results obtained by the analysis of the same samples under a variety of conditions such as different laboratories, analysts and instruments. Table-2, indicates the reproducibility upon using another model of pH-meter (Orion $261 \mathrm{~S}$ ). The obtained results are close and also reveal validity of the method.

Accuracy: The accuracy of the proposed method was investigated by the determination of alprenolol in spiked placebo samples prepared from serial concentrations of alprenolol hydrochloride reference standards. The results summarized in Table-5, show that the proposed ion selective electrode method is an accurate one for the determination of alprenolol hydrochloride in its pharmaceutical preparation without interfering from the coformulated adjuvants as indicated by the percentage recovery values.

\begin{tabular}{ccc}
\multicolumn{4}{c}{ TABLE- 5 } \\
\multicolumn{3}{c}{ DETERMINATION OF ALPRENOLOL-SPIKE } \\
PLACEBO SAMPLES USING ALPRENOLOL- \\
PHOSPHOMOLYBDATE SENSORS \\
\hline Statistical & Plastic membrane & Coated wire \\
parameters & electrode & electrode \\
\hline $\mathrm{n}$ & 9 & 9 \\
Mean $(\%)$ & 99.24 & 99.07 \\
\pm SD & 0.435 & 0.717 \\
RSD $(\%)$ & 0.438 & 0.724 \\
\hline
\end{tabular}


TABLE-6

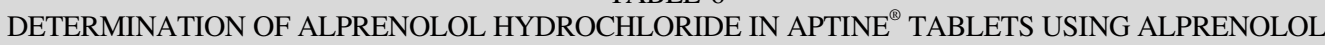
PHOSPHOMOLYBDATE SENSORS IN COMPARISON WITH OFFICIAL METHOD

\begin{tabular}{|c|c|c|c|c|c|c|}
\hline \multirow{3}{*}{$\begin{array}{l}\text { Statistical } \\
\text { parameter }\end{array}$} & \multicolumn{3}{|c|}{ Alprenolol-phosphomolybdate plastic membrane electrode } & \multicolumn{3}{|c|}{ Alprenolol-phosphomolybdate coated wire electrode } \\
\hline & \multirow{2}{*}{$\begin{array}{l}\text { Official } \\
\text { method }^{11}\end{array}$} & \multicolumn{2}{|c|}{ Direct potentiometry } & \multirow{2}{*}{$\begin{array}{l}\text { Official } \\
\text { method }^{11}\end{array}$} & \multicolumn{2}{|c|}{ Direct potentiometry } \\
\hline & & Calibration method & Standard addition method & & Calibration method & Standard addition method \\
\hline Mean $(\%)$ & 99.54 & 99.12 & 99.84 & 99.47 & 99.73 & 99.16 \\
\hline $\mathrm{n}$ & 6.00 & 6.00 & 7.00 & 6.00 & 7.00 & 7.00 \\
\hline Variance & 0.171 & 0.103 & 0.399 & 0.151 & 0.189 & 0.295 \\
\hline$\pm \mathrm{SD}$ & 0.414 & 0.321 & 0.632 & 0.389 & 0.435 & 0.543 \\
\hline $\mathrm{SE}$ & 0.169 & 0.131 & 0.239 & 0.391 & 0.164 & 0.205 \\
\hline$t$-test & & $1.964(2.228)^{*}$ & $1.025(2.201)^{*}$ & & $0.613(2.201)^{*}$ & $0.702(2.201)^{*}$ \\
\hline$F$-test & & $1.66(5.05)^{*}$ & $2.33(4.39)^{*}$ & & $1.25(4.39)^{*}$ & $1.95(4.39)^{*}$ \\
\hline
\end{tabular}

Precision: The precision of the proposed method, measured as percentage relative standard deviation (\% RDS) was tested by repeating the proposed method for determination of the investigated drug in its pharmaceutical preparations three batches to nine replicates. The $\% \mathrm{RSD}$ values for the repeated determinations were $0.610,0.749$ and $0.432 \%$ for determination of alprenolol hydrochloride in aptine ${ }^{\circledR}$ tablets using alprenolol-phosphomolybdate plastic membrane electrode. The above \% RSD values are less than $2 \%$ indicating good precision.

\section{Analytical applications of the proposed method:}

Application to pharmaceutical preparations (aptine ${ }^{\circledR}$ tablets): The proposed ion selective electrode method was applied for determination of alprenolol hydrochloride in their dosage forms. The mean $\%$ recovery found and $\%$ RSD, indicate that the proposed validated method could be adopted for the determination of the investigated drug in its pharmaceutical preparations without interference from the coformulated adjuvants. Table- 6 , shows the results obtained from the determination of alprenolol hydrochloride in tablets in comparison with official method.

Content uniformity assay of Aptine ${ }^{\circledR}$ tablets: The proposed ion selective electrode method described good accuracy and precision for the quality control tests, the content uniformity assay showed that the mean recoveries \pm standard deviations were $99.85 \pm 0.754$ and $99.35 \pm 0.529$ for electrodes (I) and (II) respectively.

\section{Conclusion}

The alprenolol-selective electrodes based on alprenololphosphomolybdate ion association in a PVC matrix exhibited useful analytical characteristics for the determination of alprenolol hydrochloride in pure form and in pharmaceutical formulations. The good recoveries and low relative standard deviations reflect the high accuracy and precision of the proposed method. Moreover, the method is simple, easy to operate and inexpensive making it an excellent tool for routine determination of alprenolol hydrochloride in quality control laboratories.

\section{ACKNOWLEDGEMENTS}

This research project was supported by a grant from the Research Center of the Center for Female Scientific and Medical Colleges in King Saud University.

\section{REFERENCES}

1. J.V. Jackson, M.S. Moss and B. Widdop, Clark's Isolation and Identification of Drugs, edn. 2, p. 331 (1986).

2. V. Ranta, E. Toropainen, A. Talvitie, A. Auriola and A. Urtti, J. Chromatogr. $B$, 772, 81 (2002).

3. M.I. Maguregui, R.M. Alonso and R.M. Jiménez, J. Chromatogr. B, 674, 85 (1995).

4. J. Hermansson and C. von Bahr, J. Chromatogr., 227, 113 (1982).

5. C. Brunelli, C. Bicchi, A. Di Stilo, A. Salomone and M. Vincenti, J. Sep. Sci., 29, 2765 (2006).

6. H. Sirén, M. Saarinen, S. Hainari, P. Lukkari and M.-L. Riekkola, J. Chromatogr. A, 632, 215 (1993).

7. T. Yamaguchi, Y. Morimoto, Y. Sekine and M. Hashimoto, J. Chromatogr. A, 239, 609 (1982).

8. L. Gagyi, Á. Gyéresi and F. Kilár, J. Biochem. Biophys. Methods, 70, 1268 (2008).

9. A. Jouyban, M. Khoubnasabjafari, S. Yeghanli, S.C. Grosse and B.J. Clark, IL Farmaco, 58, 1039 (2003).

10. H.Y. Aboul-Enein and X.S. Xian, Analusis, 28, 855 (2000).

11. European Pharmacopoeia, Electronic edition (2011).

12. Information Bull. IUPAC, No. 43, Recommendations for Nomenclature of Ion-selective Electrodes (1975).

13. E. Linder, K. Toth and E. Pungor, Dynamic Characteristics of Ion-Selective Electrodes, Chemical Rubber Company (CRC) Press, Boca Raton, FL (1988). 